\title{
Randomised in situ trial on the effect of milk and CPP-ACP on dental erosion
}

\author{
Wiegand, Annette ; Attin, Thomas
}

\begin{abstract}
OBJECTIVES This randomised in situ study aimed to analyse the effect of milk (with or without 5ppm F) and CPP-ACP pastes (with or without 900ppm F) on dental erosion. METHODS The study was a seven phase ( 5 days each) crossover design involving 15 participants wearing intraoral appliances with enamel and dentine specimens. Specimens were extraorally eroded (erosive soft drink, $6 \times 90$ s/day) and brushed $(2 \times 30 \mathrm{~s} /$ day, $2 \mathrm{~N})$ using a non-fluoridated toothpaste (negative control). The test products were milk, milk $+5 \mathrm{ppm} \mathrm{F}$ (twice daily, each $100 \mathrm{ml} / 2 \mathrm{~min}$ ), CPP-ACP paste, CPP-ACP paste+900ppm F (3min/day) or a $\mathrm{SnCl} 2 / \mathrm{AmF} / \mathrm{NaF}$ mouthrinse (positive control, 30s/day), which were applied immediately after erosion with the appliances in the oral cavity. In an additional group, a fluoridated toothpaste was used without any additional test product. Tissue loss was determined profilometrically after 5 days and statistically analysed by linear mixed models methodologies $(\mathrm{p}<0.05)$. RESULTS Compared with the negative control (non-fluoridated toothpaste only, enamel: $2.2 \pm 1.3 \mathrm{~m}$; dentine: $3.8 \pm 2.2 \mathrm{~m}$ ), enamel and dentine loss was significantly reduced by the use of fluoridated toothpaste (enamel: $1.1 \pm 1.0 \mathrm{~m}$; dentine: $2.4 \pm 1.7 \mathrm{~m})$ and the $\mathrm{SnCl} 2 / \mathrm{AmF} / \mathrm{NaF}$ mouthrinse $(1.5 \pm 1.5 \mathrm{~m}$; dentine: $1.8 \pm 1.9 \mathrm{~m})$. CONCLUSIONS Milk and CPP-ACP were not effective in reducing enamel and dentine loss significantly, independently of the presence of fluoride. CLINICAL SIGNIFICANCE Enamel and dentine erosion were significantly reduced by the use of a fluoridated toothpaste or a $\mathrm{SnCl} 2 / \mathrm{AmF} / \mathrm{NaF}$ mouthrinse, but not by milk or CPP-ACP under the conditions of the present study. CLINICAL TRIALS REGISTRATION NCT01566357.
\end{abstract}

DOI: https://doi.org/10.1016/j.jdent.2014.07.009

Posted at the Zurich Open Repository and Archive, University of Zurich

ZORA URL: https://doi.org/10.5167/uzh-99776

Journal Article

Accepted Version

Originally published at:

Wiegand, Annette; Attin, Thomas (2014). Randomised in situ trial on the effect of milk and CPP-ACP on dental erosion. Journal of Dentistry, 42(9):1210-1215.

DOI: https://doi.org/10.1016/j.jdent.2014.07.009 
Randomized in situ trial on the effect of milk and CPP-ACP on dental erosion

Short title: Effect of milk and CPP-ACP on erosion

Annette Wiegand ${ }^{1}$, Thomas Attin ${ }^{2}$

${ }^{1}$ Department of Preventive Dentistry, Periodontology and Cariology, University of Göttingen, Robert-Koch-Str. 40, 37075 Göttingen, Germany

${ }^{2}$ Department of Preventive Dentistry, Periodontology and Cariology, University of Zurich, Plattenstrasse 11, 8032 Zurich, Switzerland

\section{Corresponding author:}

Prof. Dr. Annette Wiegand

Department of Preventive Dentistry, Periodontology and Cariology

University of Göttingen

Robert-Koch-Str. 40, 37075 Göttingen

Email: annette.wiegand@med.uni-goettingen.de

Phone: 0049-551-3922884

\section{Key words:}

enamel, dentin, calcium, phosphate, fluoride, demineralization 


\title{
Randomized in situ trial on the effect of milk and CPP-ACP on dental erosion
}

\begin{abstract}
Objectives: This randomized in situ study aimed to analyse the effect of milk (with or without 5 ppm F) and CPP-ACP pastes (with or without 900 ppm F) on dental erosion.

Methods: The study was a seven phase (5 days each) crossover design involving 15 participants wearing intraoral appliances with enamel and dentin specimens. Specimens were extraorally eroded (erosive soft drink, 6 × 90s/day) and brushed $(2 \times 30$ s/day, $2 \mathrm{~N}$ ) using a non-fluoridated toothpaste (negative control). The test products were milk, milk +5 ppm F (twice daily, each $100 \mathrm{ml} / 2 \mathrm{~min}$ ), CPP-ACP paste, CPP-ACP paste $+900 \mathrm{ppm} \mathrm{F} \mathrm{(3}$ $\mathrm{min} /$ day) or a $\mathrm{SnCl}_{2} / \mathrm{AmF} / \mathrm{NaF}$ mouthrinse (positive control, $30 \mathrm{~s} /$ day), which were applied immediately after erosion with the appliances in the oral cavity. In an additional group, a fluoridated toothpaste was used without any additional test product. Tissue loss was determined profilometrically after 5 days and statistically analysed by linear mixed models methodologies $(p<0.05)$.
\end{abstract}

Results: Compared with the negative control (non-fluoridated toothpaste only, enamel: $2.2 \pm 1.3 \mu \mathrm{m}$; dentin: $3.8 \pm 2.2 \mu \mathrm{m}$ ), enamel and dentin loss was significantly reduced by the use of fluoridated toothpaste (enamel: $1.1 \pm 1.0 \mu \mathrm{m}$; dentin: $2.4 \pm 1.7 \mu \mathrm{m}$ ) and the $\mathrm{SnCl}_{2} / \mathrm{AmF} / \mathrm{NaF}$ mouthrinse $(1.5 \pm 1.5 \mu \mathrm{m}$; dentin: $1.8 \pm 1.9 \mu \mathrm{m})$.

Conclusions: Milk and CPP-ACP were not effective in reducing enamel and dentin loss significantly, independently of the presence of fluoride.

Clinical significance: Enamel and dentin erosion were significantly reduced by the use of a fluoridated toothpaste or a $\mathrm{SnCl}_{2} / \mathrm{AmF} / \mathrm{NaF}$ mouthrinse, but not by milk or CPP-ACP under the conditions of the present study.

(Clinical trials registration NCT01566357)

\section{Key words:}

enamel, dentin, calcium, phosphate, fluoride, demineralization 


\section{Introduction}

Milk is a biological fluid containing phosphoprotein/phosphopeptide-stabilized calcium phosphates, which are known to exhibit some remineralizing potential. ${ }^{1}$ Casein phosphopeptides can be extracted enzymatically from milk and complexed with calcium and phosphate to casein phosphopeptide-stabilized amorphous calcium phosphate (CPP-ACP) complexes, allowing the stabilization of high concentrations of bioavailable calcium and phosphate ions. Due to the higher amount of bioavailable calcium and phosphate, CPP-ACP is thought to have a higher remineralizing potential compared to milk . ${ }^{1}$

While the remineralizing effects of milk and CPP-ACP on carious lesions were extensively studied in the last years, little is known on the anti-erosive effect of milk or CPP-ACP. Dental erosion is caused by the direct contact with extrinsic or intrinsic acids at low $\mathrm{pH}$, but is modified by different behavioural and biological factors. Saliva plays an important role in the erosion process due to the erosion-protective effect of the salivary pellicle ${ }^{2}$ and the ability to reharden eroded dental hard tissue by mineral disposition. ${ }^{3}$ It is therefore conceivable that higher concentrations of calcium and phosphate - as present in milk or CPP-ACP - improve the rehardening of eroded lesions and thus, have the potential to slow down further dental hard tissue loss.

Rinsing with milk is known to increase the intraoral $\mathrm{pH}$ after an erosive attack $^{4}$ and the rehardening of eroded enamel compared to water rinsing. ${ }^{5,6}$ However, this does not necessarily imply that milk rinsing has a beneficial effect on further dental hard tissue loss under continuous erosive conditions.

In vitro studies on the effect of CPP-ACP on erosion presented conflicting results. While microscopical analyses suggested that CPP-ACP forms aggregates and/or precipitates on the tooth surface ${ }^{7,8}$ reducing further enamel erosion, ${ }^{9}$ other studies did not show a preventive $^{10,11}$ or remineralizing effect. ${ }^{12,13}$ The erosion-preventive effect of CPP-ACP was mostly observed when immersion periods of several hours were used. ${ }^{7,9,14}$ In situ data 
suggest that the application of a CPP-ACP-containing cream might improve the rehardening of eroded enamel, ${ }^{15}$ but is not more effective compared to a fluoride rinse. ${ }^{11}$ However, as for milk rinsing, no clinical data are available analysing the effect of CPP-ACP on erosive dental hard tissue loss over time.

The aim of the present study was to analyse the effect of rinsing with milk and the application of a CPP-ACP cream on erosive enamel and dentin wear and to compare it with a fluoridated toothpaste or a stannous-chloride containing fluoride solution (positive control). As there is some evidence that the remineralizing potential of milk and CPP-ACP is enhanced in the

presence of fluoride ${ }^{15,16}$ the use of fluoridated milk (5 ppm F, as used for milk fluoridation in cariology for caries prevention) and of CPP-ACP/900 ppm F (commercial product) was also analysed. The first hypothesis was that milk and CPP-ACP are not different from the negative control (fluoride-free toothpaste), independently of the presence of fluoride. The second hypothesis was that milk and CPP-ACP are different from the positive control $\left(\mathrm{SnCl}_{2} / \mathrm{AmF} / \mathrm{NaF}\right.$ mouthrinse), independently of the presence of fluoride.

\section{Materials \& methods}

This study was planned as a blinded, prospective, single-centre in situ study (7 phases, each of 5 days) with a crossover design and registered under NCT01566357. The study was conducted in the Center for Dental Medicine of the University of Zurich and approved by the local ethics committee (KEK-ZH-No: 2011-0153/0). The study followed the guidelines of Good Clinical Practice and conformed to the declaration of Helsinki. The report of the study followed the CONSORT statement. The principal investigator was responsible for adherence to the study protocol, the realisation of the study and the randomisation procedure. Three investigators performed all clinical and technical procedures.

\section{Participants}

Fifteen healthy adult volunteers (mean age: $33.2 \pm 7.6$ years, 3 males, 12 females) who fulfilled the inclusion criteria (physiological saliva flow rates: stimulated: $>1 \mathrm{ml} / \mathrm{min}$, 
unstimulated: $>0.25 \mathrm{ml} / \mathrm{min}$; good oral health: no frank cavities or significant gingivitis/ periodontitis) without violating the exclusion criteria (general/systemic illness, pregnancy or breastfeeding, use of fixed or removable orthodontic appliances, known allergy to the test products) were enrolled. All participants were given oral and written information about the aim of the study and the test products. All volunteers gave their informed consent.

The sample size calculation was based on a previous study. ${ }^{17} \mathrm{~A}$ difference of $1 \mu \mathrm{m}$ (enamel) or $2 \mu \mathrm{m}$ (dentin) between negative and positive control was considered to be clinically relevant. Considering a mean standard deviation of $0.4 \mu \mathrm{m}$ (enamel) and $1.3 \mu \mathrm{m}$ (dentin) found in the previous study, a sample size of $n=15$ was calculated with a power $>90 \%$. Power calculation was done with a two-sample t-test with Bonferroni correction considering relevant comparisons.

Specimen preparation, mouth appliances and tested products

Cylindric enamel and dentin specimens (each $n=315$, diameter: $3 \mathrm{~mm}$ ) were prepared from the crown or root surfaces, respectively, of freshly extracted, non-damaged bovine incisors, which were stored in $0.1 \%$ thymol solution until they were used. The specimens were prepared using a water-cooled trephine bur and embedded in acrylic resin blocks (Paladur, Heraeus Kulzer, Germany) each containing three enamel or three dentin specimens. The unique shape of the resin blocks with a round tip on one end and a cornered tip on the other allowed exact repositioning of the specimens in the intraoral appliances, the brushing machine and the profilometer. The specimens were ground flat and polished with watercooled discs (1200, 2400 and 4000 grit, Water Proof Silicon carbide Paper, Struers, Erkrath, Germany). Then, they were sterilized by $\mathrm{Y}$-radiation (12 kGy, Paul Scherrer Institute, Villigen, Switzerland), and randomly allocated to the volunteers and the respective test phases.

In each experimental phase, three enamel and three dentin specimens were fixed in the buccal aspects of custom-made acrylic maxillary appliances. The position of the resin blocks containing the enamel or dentin specimens on the right or left side of the appliance was randomly determined for each volunteer and each phase (www.randomizer.org). 
The test groups and the ingredients and manufacturers of the test products are presented in table 1.

Intervention

The study used a crossover design with seven phases of 5 days each. The order of treatments was different for all participants and was randomly assigned by generating a randomisation table (www.randomizer.org).

Participants were extensively trained prior the experiment and received written instructions and a daily time schedule for the respective treatment. Participants were not blinded due to the different test products, but the investigator performing the profilometric analysis was blinded until the end of the study.

During each experimental phase, the appliances were worn night and day except during meals ( 3 times daily, each $60 \mathrm{~min}$ ). After food intake, 30 min elapsed before the appliance was re-inserted in the oral cavity. After each experimental treatment, at least 30 min elapsed before the appliance was allowed to be removed for food intake. Outside the oral cavity, the appliances were stored in tap water. The appliances were worn overnight prior to the first experimental treatment. Procedures started between 7 and 9 a.m. After removing the appliance, volunteers performed their own oral hygiene using a manual toothbrush and fluoridated (RDA 38, group 2) or non-fluoridated (RDA 25, group 1, 3-7) toothpaste. Subsequently, each resin block with 3 specimens was brushed in a brushing machine with a sonic toothbrush (30 s, 15 brushing strokes, 2 N, Sensonic Professional SR-1000 E, Waterpik, Dübendorf, Switzerland) using $2 \mathrm{ml}$ of the respective toothpaste slurry (1 part toothpaste: 3 parts artificial saliva ${ }^{18}$ ). Thereby, the right and left sides of the specimens were covered with a stainless steel foil $(0.1-\mathrm{mm}$ thick) leaving a $2-\mathrm{mm}$ wide area in the middle of each specimen exposed for brushing and protecting reference areas (in resin) for profilometric analysis.

Ninety minutes after reinsertion in the oral cavity, the specimens were eroded extraorally by storage in $100 \mathrm{ml}$ of an erosive soft drink (Sprite, Coca-Cola, Switzerland, pH: 2.7, $90 \mathrm{~s}$ ). 
Before re-insertion in the oral cavity, volunteers drink $20 \mathrm{ml}$ of the soft drink. Erosion of the specimens was repeated 3, 6 and $9 \mathrm{~h}$ after the first erosion. Specimens were again brushed 90 min after the last erosive treatment.

Depending on the experimental phase, the volunteers had to use one additional test product: Milk was consumed immediately after the second and third erosive treatment with the appliance in the oral cavity (each time: $100 \mathrm{ml} / 2 \mathrm{~min}$ ). If milk needed to be supplemented with fluoride, this was done immediately before consumption. CPP-ACP was applied in a pea-sized amount once daily after the second erosive treatment on the blocks in the intraoral appliance, remnants were spit out after $3 \mathrm{~min}$. The $\mathrm{SnCl}_{2} / \mathrm{AmF} / \mathrm{NaF}$ mouthrinse was used once daily immediately after the second erosion treatment for $30 \mathrm{~s}$ with the appliance in the oral cavity. The specimens were subjected to profilometric measurement $1 \mathrm{~h}$ after the last brushing treatment of the 5-day-period.

Before the beginning of the experiment and between the treatment periods, a 5-day washout period was included. A flow-chart of the study procedures and the schedule of daily experiments is presented in figure 1.

\section{Profilometric measurement}

Enamel or dentin loss, respectively, was defined as primary outcome. Dental hard tissue loss was analysed profilometrically using a mechanical profilometer (Perthometer S2, Mahr, Göttingen, Germany). From each specimen, 5 baseline surface profiles were recorded with a distance of $100 \mu \mathrm{m}$ between each profile. The profiles were obtained by moving the diamond stylus across the dental hard tissue surface and the references areas perpendicularly to the direction of the movement of the toothbrush. This assessment was done at baseline and after completion of the experiment.

Calculation was done using the software of the profilometer (4D Client, University Zurich, Zurich Switzerland), which allows exact superimposition of the reference areas (acidresistant acrylic resin) and profiles recorded at baseline and at the end of the experiment. 


\section{Statistical analysis}

Data were coded in excel and analysed with SPSS version 16 (IBM). For each volunteer and each treatment group, all three enamel or dentin specimens, respectively, were considered for statistical analysis. Due to inherent clumping in the measurements, linear mixed models methodologies were applied $(p<0.05)$.

\section{Results}

All participants completed the study and all specimens were measured profilometrically. No adverse side-effects were observed.

In enamel, erosive/abrasive loss in the negative control group amounted to $2.2 \pm 1.3 \mu \mathrm{m}$. A significant reduction was achieved by the use of fluoridated toothpaste (by $50 \%$ ) or the $\mathrm{SnCl}_{2} / \mathrm{AmF} / \mathrm{NaF}$ mouthrinse (positive control, by $32 \%$ ).

In dentin, erosive/abrasive loss of the negative control amounted to $3.8 \pm 2.2 \mu \mathrm{m}$ and was significantly reduced by fluoridated toothpaste (by $37 \%$ ) and the $\mathrm{SnCl}_{2} / \mathrm{AmF} / \mathrm{NaF}$ mouthrinse (positive control, by 53\%). Enamel and dentin wear are presented in Table 2.

\section{Discussion}

This study showed that milk and CPP-ACP-containing creams were not effective at reducing erosive enamel and dentin loss significantly, independently of the presence of 5 or $900 \mathrm{ppm}$ fluoride, respectively. Therefore, both hypotheses were accepted.

Following recent recommendations for erosion/abrasion studies, the specimens were frequently exposed to short erosive cycles, simulating rather severe erosive conditions in patients with a high consumption of soft drinks. As specimens were eroded extraorally, volunteers were asked to consume a sip of the soft drink prior to re-insertion of the specimens in the oral cavity to induce a $\mathrm{pH}$ drop of saliva. ${ }^{19}$ Bovine instead of human specimens as both substrates perform similar in erosion/abrasion studies and relative rather 
than absolute differences are of relevance. Brushing of the specimens was performed twice daily using a fluoridated or non-fluoridated toothpaste of similar abrasivity, ensuring that the abrasive challenge was similar in all groups. ${ }^{20}$

All test products were applied intraorally immediately after the erosive attack to allow for a maximum effect by neutralising the salivary $\mathrm{pH}$ and/or providing active ingredients (calcium, phosphate, proteins, fluoride, tin) to control the de- and remineralisation process. The administration of milk (100 ml twice daily) followed an analysis of food habits in Europe, where it was shown that milk consumption varies between $130-540 \mathrm{~g} / \mathrm{day} .{ }^{21}$ The CPP-ACPcontaining products and the $\mathrm{SnCl}_{2} / \mathrm{AmF} / \mathrm{NaF}$ mouthrinse were applied following the recommendations of the manufacturers. As expected from previous clinical studies, ${ }^{22,23}$ the $\mathrm{SnCl}_{2} / \mathrm{AmF} / \mathrm{NaF}$ mouthrinse reduced erosive loss in enamel and dentin significantly. Also, the amine fluoride-containing toothpaste was effective in reducing erosive hard tissue loss compared to the negative control group. Thereby, the degree of protection found for the fluoride-containing toothpaste is in the range of previously reported studies, showing that conventional toothpastes containing sodium or amine fluoride reduce wear of eroded dental hard tissues by around $30 \%$ compared to fluoride-free formulations. ${ }^{24}$

Rinsing the oral cavity with milk immediately after an erosive attack did not reduce the erosive wear. It is speculated that the degree of remineralisation of the erosively demineralised enamel or dentin surface by providing additional calcium ions is probably too low to be relevant under severe erosive conditions including an abrasive component like toothbrushing. In this context, the addition of $5 \mathrm{ppm}$ fluoride was unable to provide any additional beneficial effect. However, fluoride might partially interact with calcium or might be incorporated into milk proteins so that the formation of calcium fluoride precipitates in relevant amounts on the enamel and dentin surfaces is probably very limited.

Also, both formulations of the CPP-ACP paste were also unable to reduce the erosive wear significantly. Under acidic conditions, milk proteins show a poor affinity to tooth surfaces as both casein micelles and hydroxyapatite surfaces are supposed to be positively charged at $\mathrm{pH}$ below 5 , thus reducing their electrostatic interactions. ${ }^{12,25}$ Precipitates observed after 
application of the CPP-ACP pastes were shown to scatter over the surface resulting in a nonhomogenous layer, ${ }^{8,12}$ which is probably dissolved by acid contact. Additionally, the surface precipitates might be mechanically removed by toothbrushing. Even the fluoridated CPPACP paste did not present a better effect than the CPP-ACP paste without fluoride. Free fluoride activity of MI Paste Plus was shown to be distinctly lowered to $12.2 \mathrm{ppm}$, probably generating only a limited amount of fluoride precipitates on the surface. ${ }^{12}$ In summary, this study has shown that milk and CPP-ACP were ineffective in reducing erosive wear in enamel and dentin.

\section{Acknowledgement}

This study was supported by a grant of the Borrow-Foundation (USZ/029). The authors are very thankful to the volunteers for their participation.

The authors declare that they have no potential conflict of interest. 


\section{Table Legends}

Table 1. Test groups of the present study. Volunteers in groups $3-7$ used the fluoride-free toothpaste for own oral hygiene and for brushing of the specimens.

Table 2. Enamel and dentin wear in the different test groups.

* groups that are significantly different from the negative control

${ }^{\circ}$ groups that are significantly different from the positive control 


\section{References}

1. Cross KJ, Huq NL, Reynolds EC. Casein phosphopeptides in oral health--chemistry and clinical applications. Current Pharmaceutical Design 2007; 13: 793-800.

2. Wiegand A, Bliggenstorfer S, Magalhaes AC, Sener B, Attin T. Impact of the in situ formed salivary pellicle on enamel and dentine erosion induced by different acids. Acta Odontologica Scandinavica 2008; 66: 225-230.

3. Rios D, Honorio HM, Magalhaes AC, Silva SM, Delbem AC, Machado MA et al. Scanning electron microscopic study of the in situ effect of salivary stimulation on erosion and abrasion in human and bovine enamel. Brazilian Oral Research 2008; 22: 132-138.

4. Lindquist $B$, Lingstrom $P$, Fandriks $L$, Birkhed $D$. Influence of five neutralizing products on intra-oral $\mathrm{pH}$ after rinsing with simulated gastric acid. European Journal of Oral Sciences 2011; 119: 301-304.

5. Gedalia I, Dakuar A, Shapira L, Lewinstein I, Goultschin J, Rahamim E. Enamel softening with Coca-Cola and rehardening with milk or saliva. American Journal of Dentistry 1991; 4: 120-122.

6. Wiegand A, Muller I, Schnapp JD, Werner C, Attin T. Impact of fluoride, milk and water rinsing on surface rehardening of acid softened enamel. An in situ study. American Journal of Dentistry 2008; 21: 113-118.

7. Poggio C, Lombardini M, Dagna A, Chiesa M, Bianchi S. Protective effect on enamel demineralization of a CPP-ACP paste: an AFM in vitro study. Journal of Dentistry 2009; 37: 949-954.

8. Poggio C, Lombardini M, Vigorelli P, Ceci M. Analysis of dentin/enamel remineralization by a CPP-ACP paste: AFM and SEM study. Scanning 2013; in press.

9. Rees J, Loyn T, Chadwick B. Pronamel and tooth mousse: an initial assessment of erosion prevention in vitro. Journal of Dentistry 2007; 35: 355-357. 
10. Lennon AM, Pfeffer M, Buchalla W, Becker K, Lennon S, Attin T. Effect of a casein/calcium phosphate-containing tooth cream and fluoride on enamel erosion in vitro. Caries Research 2006; 40: 154-157.

11. Wegehaupt FJ, Tauböck TT, Stillhard A, Schmidlin PR, Attin T. Influence of extra- and intra-oral application of CPP-ACP and fluoride on re-hardening of eroded enamel. Acta Odontologica Scandinavica 2012; 70: 177-183.

12. Wang X, Megert B, Hellwig E, Neuhaus KW, Lussi A. Preventing erosion with novel agents. Journal of Dentistry 2011; 39: 163-170.

13. Turssi CP, Maeda FA, Messias DC, Neto FC, Serra MC, Galafassi D. Effect of potential remineralizing agents on acid softened enamel. American Journal of Dentistry 2011; 24: $165-168$

14. Tantbirojn D, Huang A, Ericson MD, Poolthong S. Change in surface hardness of enamel by a cola drink and a CPP-ACP paste. Journal of Dentistry 2008; 36: 74-79.

15. Srinivasan N, Kavitha M, Loganathan SC. Comparison of the remineralization potential of CPP-ACP and CPP-ACP with 900ppm fluoride on eroded human enamel: An in situ study. Archives of Oral Biology 2010; 55: 5541-544.

16. Malinowski M, Duggal MS, Strafford SM, Toumba KJ. The effect of varying concentrations of fluoridated milk on enamel remineralisation in vitro. Caries Research 2012; 46: 555-560.

17. Wiegand A, Hiestand B, Sener B, Magalhaes AC, Roos M, Attin T. Effect of TiF4, ZrF4, HfF4 and AmF on erosion and erosion/abrasion of enamel and dentin in situ. Archives of Oral Biology 2010; 55: 223-228.

18. Klimek J, Hellwig E, Ahrens G. Fluoride taken up by plaque, by the underlying enamel and by clean enamel from 3 fluoride compounds in vitro. Caries Research 1982; 16: 156-161.

19. Millward A, Shaw L, Harrington E, Smith AJ. Continuous monitoring of salivary flow rate and $\mathrm{pH}$ at the surface of the dentition following consumption of acidic beverages. Caries Research 1997; 31: 44-49.

20. Wiegand A, Attin T. Design of erosion/abrasion studies--insights and rational concepts. Caries Research 2011; 45 Suppl 1: 53-59. 
21. Sanchez-Villegas A, Martinez JA, Prättälä R, Toledo E, Roos G, Martinez-Gonzales MAftFg. A systematic review of socioeconomic differences in food habits in Europe: consumption of cheese and milk. European Journal Clinical Nutrition 2003; 57: 917929.

22. Ganss C, Neutard L, von Hinckeldey J, Klimek J, Schlueter N. Efficacy of a tin/fluoride rinse: a randomized in situ trial on erosion. Journal of Dental Research 2010; 89: 12141218.

23. Schlueter N, Klimek J, Ganss C. Efficacy of tin-containing solutions on erosive mineral loss in enamel and dentine in situ. Clinical Oral Investigations 2011; 15: 361-367

24. Ganss C, Schulze K, Schlueter N. Toothpaste and erosion. Monographs in Oral Science 2013; 23: 88-99.

25. Barbour ME, Shellis RP, Parker DM, Allen GC, Addy M. Inhibition of hydroxyapatite dissolution by whole casein: the effects of $\mathrm{pH}$, protein concentration, calcium, and ionic strength. European Journal of Oral Sciences 2008; 116: 473-478. 


\begin{tabular}{|c|c|c|c|c|}
\hline No & Test group & Application procedure & $\begin{array}{c}\text { Product/ } \\
\text { manufacturer }\end{array}$ & Ingredients \\
\hline 1 & $\begin{array}{l}\text { Fluoride-free } \\
\text { toothpaste } \\
\text { (negative } \\
\text { control) }\end{array}$ & Brushing twice daily & $\begin{array}{l}\text { Calendula, } \\
\text { Weleda, } \\
\text { Arlesheim, } \\
\text { Switzerland }\end{array}$ & $\begin{array}{l}\text { Water, Calcium Carbonate, } \\
\text { Glycerin, Magnesium Aluminum } \\
\text { Silicate, Alcohol, Calendula } \\
\text { Officinalis Extract, Commiphora } \\
\text { Myrrha Resin Extract, Xanthan } \\
\text { Gum, Ammonium Glycyrrhizate, } \\
\text { Flavor (Aroma), Limonene } \\
\end{array}$ \\
\hline 2 & $\begin{array}{l}\text { Fluoridated } \\
\text { toothpaste }\end{array}$ & Brushing twice daily & $\begin{array}{c}\text { Elmex, } \\
\text { GABA, } \\
\text { Switzerland }\end{array}$ & $\begin{array}{c}\text { Aqua, Sorbitol, Hydrated silica, } \\
\text { Hydroxyethylcellulose, Olaflur (1250 } \\
\text { ppm F), Aroma, Limonene, Titanium } \\
\text { dioxide, Saccharin }\end{array}$ \\
\hline 3 & Milk & $\begin{array}{c}\text { Drinking, twice daily after } \\
\text { erosion (each time: } 100 \\
\mathrm{ml} / 2 \mathrm{~min})\end{array}$ & $\begin{array}{l}\text { Whole milk } \\
\text { (UHT, } 3.5 \% \\
\text { fat), Coop, } \\
\text { Switzerland }\end{array}$ & 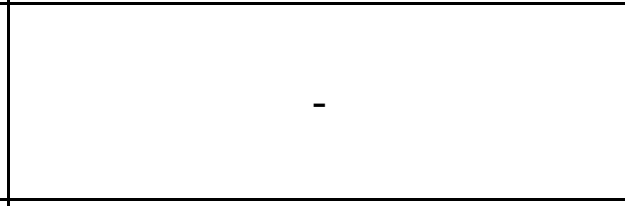 \\
\hline 4 & $\begin{aligned} & \text { Milk } \\
+ & 5 \mathrm{ppm} \mathrm{F}\end{aligned}$ & $\begin{array}{c}\text { Drinking, twice daily after } \\
\text { erosion (each time: } 100 \\
\mathrm{ml} / 2 \mathrm{~min})\end{array}$ & $\begin{array}{l}\text { Whole milk } \\
\text { (UHT, 3.5\% } \\
\text { fat), Coop, } \\
\text { Switzerland }\end{array}$ & $\begin{array}{l}\text { Supplemented with } 5 \text { ppm F (NaF, } \\
\text { Merck, Darmstadt, Germany) }\end{array}$ \\
\hline 5 & CPP-ACP & $\begin{array}{c}\text { Application once daily } \\
\text { after erosion, pea-sized } \\
\text { amount }\end{array}$ & $\begin{array}{c}\text { Tooth mousse, } \\
\text { GC, } \\
\text { Flums, } \\
\text { Switzerland }\end{array}$ & $\begin{array}{c}\text { Water, glycerol, CPP-ACP (10\%), } \\
\text { D-sorbitol, CMC-Na, Propylene } \\
\text { glycol, Silicon dioxide, Titanium } \\
\text { dioxide, Xylitol, Phosphoric acid, } \\
\text { Flavoring, Sodium saccharin, Ethyl } \\
\text { p-hydroxybenzoate, Propyl p- } \\
\text { hydroxybenzoate, Butyl p- } \\
\text { hydroxybenzoate }\end{array}$ \\
\hline 6 & $\begin{array}{l}\text { CPP-ACP } \\
+900 \text { ppm F }\end{array}$ & $\begin{array}{l}\text { Application once daily } \\
\text { after erosion, pea-sized } \\
\text { amount }\end{array}$ & $\begin{array}{l}\text { MI Paste Plus, } \\
\text { GC, Flums, } \\
\text { Switzerland }\end{array}$ & $\begin{array}{l}\text { Water, glycerol, CPP-ACP (10\%), } \\
\text { D-sorbitol, CMC-Na, Propylene } \\
\text { glycol, Silicon dioxide, Titanium } \\
\text { dioxide, Xylitol, Phosphoric acid, } \\
\text { Sodium fluoride (900 ppm), } \\
\text { Flavoring, Sodium saccharin, Ethyl } \\
\text { p-hydroxybenzoate, Propyl p- } \\
\text { hydroxybenzoate, Butyl p- } \\
\text { hydroxybenzoate }\end{array}$ \\
\hline 7 & $\begin{array}{c}\mathrm{SnCl}_{2} / \mathrm{AmF} / \mathrm{NaF} \\
\text { mouthrinse } \\
\text { (positive } \\
\text { control) }\end{array}$ & $\begin{array}{l}\text { Rinsing once daily after } \\
\text { erosion }(30 \mathrm{ml} / 30 \mathrm{~s})\end{array}$ & \begin{tabular}{|} 
elmex \\
EROSION \\
PROTECTION, \\
GABA, \\
Switzerland
\end{tabular} & $\begin{array}{l}\text { Water, Glycerin, Sodium gluconate, } \\
\text { PEG-40, Hydrogenated castor oil, } \\
\text { Olaflur, Aroma, Stannous chloride, } \\
\text { Sodium fluoride, Cocamidopropyl } \\
\text { betaine, Sodium saccharin, } \\
\text { Hydrochloric acid }\end{array}$ \\
\hline
\end{tabular}

Table 1. Test groups of the present study. Volunteers in groups $3-7$ used the fluoride-free toothpaste for own oral hygiene and for brushing of the specimens. 


\begin{tabular}{|c|c|c|}
\hline Test group & $\begin{array}{c}\text { Enamel loss } \\
(\boldsymbol{\mu m}, \text { mean } \pm \mathbf{S D})\end{array}$ & $\begin{array}{c}\text { Dentin loss } \\
(\boldsymbol{\mu m}, \text { mean } \pm \mathbf{S D})\end{array}$ \\
\hline Fluoride-free toothpaste (negative control) & $2.2 \pm 1.3^{\circ}$ & $3.8 \pm 2.2^{\circ}$ \\
\hline Fluoridated toothpaste & $1.1 \pm 1.0^{*}$ & $2.4 \pm 1.7^{*}$ \\
\hline Milk & $1.8 \pm 0.9$ & $4.0 \pm 1.8^{\circ}$ \\
\hline Milk + 5 ppm F & $2.2 \pm 1.3^{\circ}$ & $3.3 \pm 2.1^{\circ}$ \\
\hline CPP-ACP & $3.1 \pm 2.5^{\star \circ}$ & $4.4 \pm 2.5^{\circ}$ \\
\hline CPP-ACP + 900 ppm F & $2.2 \pm 2.4^{\circ}$ & $3.5 \pm 2.1^{\circ}$ \\
\hline $\mathrm{SnCl}_{2} / \mathrm{AmF} / \mathrm{NaF}$ mouthrinse (positive control) & $1.5 \pm 1.5^{*}$ & $1.8 \pm 1.9^{*}$ \\
\hline
\end{tabular}

Table 2. Enamel and dentin wear in the different test groups.

* groups that are significantly different from the negative control

${ }^{\circ}$ groups that are significantly different from the positive control 
Screening of volunteers, information about study procedure, time for consideration

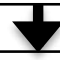

Written informed consent, inclusion of participants $(n=15)$

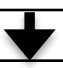

Preparation of enamel and dentin specimens, manufacturing of appliances

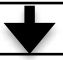

Randomisation of specimens and treatments

\begin{tabular}{|c|c|}
\hline \multicolumn{2}{|c|}{ Randomisation of specimens and treatments } \\
\hline Washout period (5d), 1st study period ( $5 \mathrm{~d}$ ) & $\begin{array}{l}\text { Brushing abrasion of specimens, } \\
\text { Toothbrushing of own teeth }\end{array}$ \\
\hline Washout period ( $5 \mathrm{~d}$ ), 2nd study period ( $5 \mathrm{~d}$ ) & Erosion \\
\hline Washout period $(5 \mathrm{~d}), 3$ rd study period $(5 \mathrm{~d})$ & $\checkmark 3 h$ \\
\hline \multirow{4}{*}{ Washout period $(5 \mathrm{~d}), 3$ rd study period $(5 \mathrm{~d})$} & Erosion \\
\hline & $\begin{array}{l}\text { If applicable: } \\
\text { application of test product }\end{array}$ \\
\hline & $\checkmark 3 h$ \\
\hline & Erosion \\
\hline Washout period ( $5 d)$, 5th study period ( $5 d$ ) & $\begin{array}{l}\text { If applicable: } \\
\text { application of test product } \\
\text { (milk or fluoridated milk) }\end{array}$ \\
\hline Washout period ( $5 \mathrm{~d}), 6$ th study period $(5 \mathrm{~d})$ & Erosion \\
\hline & $\downarrow 1.5 \mathrm{~h}$ \\
\hline Washout period $(5 d), 7$ th study period $(5 d)$ & $\begin{array}{l}\text { Brushing abrasion of specimens, } \\
\text { Toothbrushing of own teeth }\end{array}$ \\
\hline Profilometr & \\
\hline
\end{tabular}

Figure 1. Flow chart of study procedures and daily schedule of experiments 